\title{
Effect of Egg Storage Length on Hatchability and Weight Loss in Incubation of Egg and Meat Type Japanese Quails
}

\section{Author(s)}

Romao JM

Moraes TGV

Teixeira RSC

Cardoso WM

Buxade CC

Laboratório de Estudos Ornitológicos da Faculdade de Veterinária da Universidade Estadual do Ceará

\section{Mail Address}

\section{Josué Moura Romão}

Rua Dr. Alfredo Weyne 100

Apto. 701-A. Bairro de Fátima

60.415-520. Fortaleza, CE, Brazil.

Fone: (85) 32562225 ou (85) 91960054

E-mail: josueromao@yahoo.com.br william.maciel@uol.com.br

\section{Keywords}

Egg weight loss, incubation, Japanese quail, storage.

\section{ABSTRACT}

The quail raising in Brazil has increased through the last years and the incubation procedures are important to maintenance and improvement of quail egg production. To obtain a sufficient number of eggs to fill an incubator, eggs are usually accumulated in storage over a period from 1 day up to 3 weeks before incubation. The objective of this research was to verify the effect of egg storage on hatchability and egg weight loss for two lineages of Japanese quails. Sixty four Japanese quails were divided in two groups: $G 1(n=32)$ for meat production and $\mathrm{G} 2$ ( $n=32$ ) for egg production. They were used for serial egg collections that were performed every day, during 15 consecutively days, totaling 600 eggs. After collection they were placed in refrigerated room $\left(20^{\circ} \mathrm{C}\right.$ and $60 \%$ of relative humidity) and submitted to different periods of storage, from 0 day until 14 days, according to their collection day. The incubation occurred at $37.6^{\circ} \mathrm{C}$ and $60 \% \mathrm{RH}$. The weight measurements were done during storage, incubation and hatching. The results showed that for Meat type and Egg type quails, the egg hatchability was around $84 \%$ until 10 days of storage, and then this rate decreased significantly. Both types of quail eggs presented similar weight loss during storage and incubation. The research showed that quail eggs present great hatchability until 10 days of storage and that eggs submitted to storage present a reduced weight loss during incubation.

\section{INTRODUCTION}

Quail production in Brazil has increased during the last few years. In 2002, 9.25 millions dozen quail eggs were produced by 5,572,068 birds, which yielded a revenue of $R \$ 48$ millions (IBGE, 2002). The incubation procedures are important for maintenance and improvement of quail egg production. In broiler production, in order to obtain a sufficient number of eggs to fill an incubator, eggs are usually accumulated under storage for 1 day to 3 weeks before incubation (Kuurman et al., 2002). In order to prevent embryonic development during the storage period, eggs must be stored at low temperature. For eggs stored for less than 4 days, egg room temperature should be $20-25^{\circ} \mathrm{C}$, whereas for those stored 4-7 days, temperature should be maintained between 16 and $17^{\circ} \mathrm{C}$, and for eggs stored for more than 7 days, temperature should be lowered to $10-12^{\circ} \mathrm{C}$ (Meijerhof, 1992). Storage causes egg water loss by evaporation, which rate is influenced by temperature and relative humidity. Studies report that long storage periods are detrimental to table- and hatching-egg quality (Samli et al., 2005; Scott et al., 2000; Walsh et al., 1995). Water loss is a normal process during incubation; 12 to $14 \%$ of water are usually lost by broiler and turkey eggs (Rahn et al., 1981). However, if water loss is too low or too high, embryo development is affected (Rahn \& Ar, 1974), and, consequently, egg 
hatchability (Meir et al., 1984). An increase in the number of storage days elevates embryo mortality rate during storage and incubation, and thereby increases the probability of failure to hatch (Whitehead et al., 1985; Yoo \& Wientjes, 1991; Scott \& Mackenzie, 1993). Some researchers reported hatchability reductions of as much as $5 \%$ per day after 7 days of storage (Mayes \& Takeballi, 1984). As compared to literature on Gallus gallus incubation, there are few studies on incubation techniques for Japanese quails strains. The objective of this study was to verify the effect of egg storage on hatchability and egg weight loss for two strains of Japanese quails.

\section{MATERIAL AND METHODS}

This experiment was performed at Laboratório de Estudos Ornitológicos da Universidade Estadual do Ceará. A total number of 64 Japanese quails were divided in two groups according to strain: 32 meat-type birds, and 32 layer birds. Birds were housed in experimental battery cages with three females and one male per cage. Initial age was 4 month age, and average egg production was $90 \%$. All quails were supplied ad libitum with water and 17 hours/day of light were provided.

Eggs were daily collected at 05:00 pm. Eggs were submitted to selection according to industrial parameters for egg incubation, which included egg shape, extreme sizes, and eggshell intactness by candling. Twenty eggs from each quail strain were daily selected for 15 consecutive days, totaling 600 eggs. After daily collection, eggs were stored in a refrigerated room at $20^{\circ} \mathrm{C}$ and $60 \%$ of relative humidity. These eggs were divided into different experimental groups according to strain and storage length under refrigeration, which varied from 0 to 14 days, according to their collection day.

Table 1 shows egg mean weight and storage length according to group.

All eggs were weighed on their collection day and daily during the storage period to check egg weight loss with a precision scale $(0.01 \mathrm{~g}$ precision). Eggs were also weighed during incubation period at the $2^{\text {nd }}, 4^{\text {th }}$, $6^{\text {th }}, 8^{\text {th }}, 10^{\text {th }}, 12^{\text {th }}$, and $14^{\text {th }}$ day of incubation. All quail chicks and eggshells were weighed after hatching.

Incubation was carried out in automatic Premium Ecológica ${ }^{\circledR}$ incubators and hatchers, with a capacity for 300 quail eggs each capacity. The models of the incubators and hatchers were IP-130 and NP-130, respectively. Eggs were incubated at a temperature of $37.6^{\circ} \mathrm{C}$, relative humidity of $60 \%$, and egg turning in every 30 minutes. At day 14 of incubation (336h), egg turning was stopped, and eggs were transferred to the hatchers, which maintained the same temperature and relative humidity until hatch.

Eggs were divided into 30 experimental groups, according to quail strain and pre-incubation storage length. There were four replications of five eggs per treatment. Hatchability and egg weight loss means were submitted to regression analysis. Regression equation and coefficient of determination $\left(R^{2}\right)$ were obtained for each dependent variable.

\section{RESULTS AND DISCUSSION}

The trend lines for hatchability of egg- and meattype quail eggs submitted to different storage periods (0-14 days) are shown in Figure 1.

Both types of Japanese quail eggs presented a reduction of hatching rates as storage length increased. Egg-type quail eggs presented higher hatchability along egg storage as compared to meat-type quail eggs.

\begin{tabular}{|c|c|c|c|c|c|}
\hline \multirow[b]{2}{*}{ Groups } & \multicolumn{2}{|c|}{ Egg type quails } & \multirow[b]{2}{*}{ Groups } & \multicolumn{2}{|c|}{ Meat type quails } \\
\hline & Storage length (days) & Egg weight mean (g) & & Storage length (days) & Egg weight mean (g) \\
\hline $\mathrm{E}-0$ & 0 & 10.20 & $M-0$ & 0 & 13.10 \\
\hline$E-1$ & 1 & 10.30 & $M-1$ & 1 & 13.15 \\
\hline$E-2$ & 2 & 10.60 & $M-2$ & 2 & 13.05 \\
\hline$E-3$ & 3 & 11.05 & $M-3$ & 3 & 12.80 \\
\hline$E-4$ & 4 & 11.05 & $M-4$ & 4 & 12.80 \\
\hline$E-5$ & 5 & 10.95 & $M-5$ & 5 & 12.95 \\
\hline$E-6$ & 6 & 11.15 & $M-6$ & 6 & 12.65 \\
\hline E-7 & 7 & 11.05 & $M-7$ & 7 & 12.80 \\
\hline$E-8$ & 8 & 10.95 & $M-8$ & 8 & 12.80 \\
\hline E-9 & 9 & 10.85 & $M-9$ & 9 & 12.95 \\
\hline$E-10$ & 10 & 10.80 & $M-10$ & 10 & 12.80 \\
\hline E-11 & 11 & 11.10 & $M-11$ & 11 & 12.85 \\
\hline E-12 & 12 & 10.70 & $M-12$ & 12 & 13.10 \\
\hline E-13 & 13 & 10.85 & $M-13$ & 13 & 13.10 \\
\hline E-14 & 14 & 10.65 & $M-14$ & 14 & 12.85 \\
\hline
\end{tabular}


Romao JM, Moraes TGV, Teixeira RSC, Cardoso WM, Buxade CC

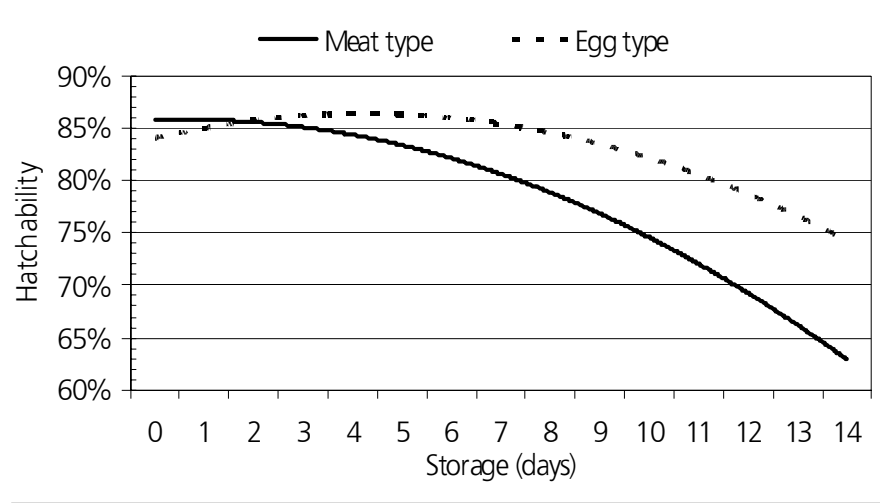

Figure 1 - Percentage of hatchability to Meat type and Egg type quail eggs at different periods of storage.

Egg-type quail eggs presented $85 \%$ average hatchability up to 10 days of storage, whereas meattype quail eggs had an average of $83 \%$. Total hatchability was $83 \%$ for egg-type quails and $78 \%$ for meat-type quails at 14 days of storage. Regression analysis of hatchability as a function of storage length gave the following regression equation $\left(y=-0.0013 x^{2}\right.$ $+0.0042 x+0.8545)$ and $R^{2}(0.4559)$ for meat-type quails and the regression equation $\left(y=-0.0013 x^{2}+\right.$ $0.0134 x+0.8282), R^{2}(0.1848)$ for egg-type quails. Meat-type quails had a better coefficient of regression as compared to egg-type quails. However, both coefficients of regression were low, and therefore the predicting models for hatchability of eggs submitted to storage are not very precise.

It was reported that egg storage prior to incubation can have both detrimental and beneficial effects (Brake et al., 1993). Excessively long storage before incubation reduces hatchability (Becker, 1964). On the other hand, other studies reported that eggs stored for a few days presented higher hatchability than those set in an incubator immediately after lay (Asmudndson \& MacLlriath, 1948). Sittmann et al. (1971) studied the hatchability quail eggs stored from 4 up to 38 days $\left(13.3^{\circ} \mathrm{C}\right)$ and found $78.6 \%$ hatchability for 4 days, $76.9 \%$ for 8 days, and $72.4 \%$ for 13 days of storage. According to Meijerhof (1992), eggs stored for more than 7 days should be held at $10-12^{\circ} \mathrm{C}$, as well as Sittmann et al. (1971). However, we verified better hatchability after two weeks of storage at a higher temperature $\left(20^{\circ} \mathrm{C}\right)$. Petek et al. (2005) observed hatchabilities of $85.8 \%, 88.3 \%, 83.8$, and $82.3 \%$ for $1,3,5$ and 7 days of storage at $18^{\circ} \mathrm{C}$ with turning twice a day in Pharaoh quails, which are members of the Coturnix family (Shanaway, 1998). The hatchability of quail eggs stored for 14 days (67.5\%) was lower than
Effect of Egg Storage Length on Hatchability and Weight Loss in Incubation of Egg and Meat Type Japanese Quails

chicken eggs (70.5\%) (Fasenko et al, 2001a) and higher than turkey eggs (65.6\%) stored for the same period (Fasenko et al, 2001b). However, the storage temperatures used by Fasenko et al. (2001ab) for chicken and turkey eggs $\left(11.5^{\circ} \mathrm{C}\right.$ and $17.4^{\circ} \mathrm{C}$, respectively) were lower than those used in the present study.

Excessive storage duration can negatively affect hatchability. Evidence of necrosis and regressive changes in the blastoderm have been reported even at storage temperatures of $13^{\circ} \mathrm{C}$ (Arora \& Kosin, 1966; Mather \& Laughlin, 1979), as well as shrinking of the blastoderm at $10^{\circ} \mathrm{C}$ (Funk \& Bieller, 1944; Mather \& Laughlin, 1979).

Figures 2 and 3 show the trend lines for percentage of egg weight loss during storage period and incubation up transference the hatcher for eggs stored from 0 to 14 days.

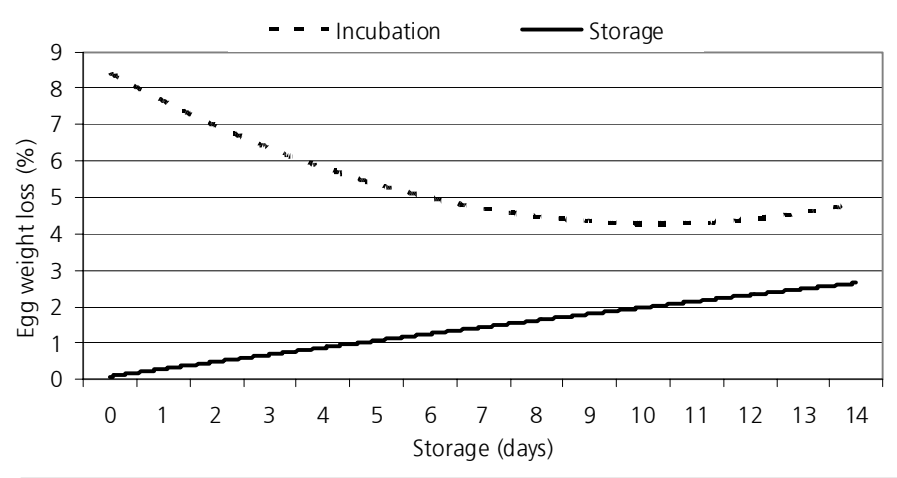

Figure 2 - Percentage of egg weight loss during storage and incubation of Meat type quail eggs.

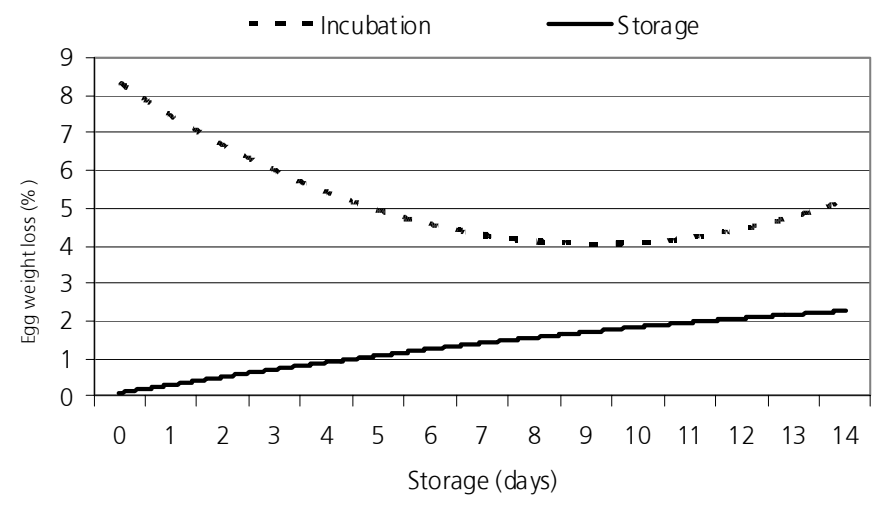

Figure 3 - Percentage of egg weight loss during storage and incubation of Egg type quail eggs.

Meat-type quail eggs presented continuous egg weight loss with storage length, reaching $2.72 \%$ at 14 days of storage at $20^{\circ} \mathrm{C}$. During the incubation period, eggs tended to decrease the rate of egg weight loss as storage length increased. The eggs stored for 0 days 
presented $8.27 \%$ of weight loss, whereas those stored for 14 days showed $4.40 \%$ of loss.

Regression analysis of egg weight loss gave the following regression equation: $\left(y=-0.0014 x^{2}+0.2058 x\right.$ $-0.1161)$ and $R^{2}(0.9947)$ for storage period and regression equation $\left(y=0.0394 x^{2}-0.8864 x+9.261\right)$ and $R^{2}(0.9183)$ for incubation period of meat-type quail eggs. Meat-type quail eggs presented high coefficients of regression for egg weight loss during storage and incubation, indicating that these are suitable models for predicting weight loss of meat-type quail eggs stored at $20^{\circ} \mathrm{C}$ for up to 14 days and then incubated at $37.6^{\circ} \mathrm{C}$ with $60 \% \mathrm{RH}$.

Egg-type quail eggs lost $2.39 \%$ of their weight during two weeks of storage. Eggs stored for 0 days lost $9.31 \%$ during incubation, and those stored for 14 days lost $4.80 \%$.

The regression analysis for egg weight loss gave the following regression equation: $\left(y=-0.0047 x^{2}+\right.$ $0.2317 x-0.1336)$ and $R^{2}(0.9909)$ for storage period and the regression equation $\left(y=0.0505 x^{2}-1.0316 x+\right.$ 9.3189) and $R^{2}$ (0.7554) for incubation period of eggtype quail eggs. These eggs presented a high and a moderate coefficient of regression for egg weight loss during storage and incubation, respectively. Therefore, the regression equation found for storage is an adequate model for predicting egg weight loss of eggtype quail eggs stored at $20^{\circ} \mathrm{C}$ and $60 \% \mathrm{RH}$. The regression equation for weight loss during incubation can also be a useful prediction tool, despite its lower $R^{2}$.

Meat-type quail eggs lost $8.27 \%$ with no storage, and $7.12 \%$ for 14 days of storage. Egg-type quail eggs lost $9.31 \%$ for 0 and $7.20 \%$ for 14 days of storage. Soliman et al. (1994) observed $11.3 \%$ egg weight loss until 15 days of incubation of hatched quail eggs. Egg weight loss can be highly influenced by relative humidity during storage and storage length. Although relative humidity during storage is not extremely critical (Funk \& Forward, 1960), it appears that only eggs from older flocks with poorer albumen quality are sensitive to lower humidity (Walsh, 1993), which may explain why Kaufman (1939) concluded that moisture loss was not the reason for high mortality after long-term storage.

As compared to Samli et al. (2005), who studied weight loss of chicken eggs stored for 2, 5, and 10 days $\left(21^{\circ} \mathrm{C}\right.$ and $55-60 \%$ of $\left.\mathrm{RH}\right)$, weight loss of quail eggs of the present experiment increased, despite being stored at lower temperature $\left(20^{\circ} \mathrm{C}\right)$. Chicken eggs (Samli et al., 2005) stored for 2, 5, and 10 days lost $0.50 \%, 1.02 \%$, and $1.66 \%$ of their weight, respectively. Meat-type quail eggs, for the same storage days, lost $0.50 \%, 1.16 \%$, and $1.94 \%$. Egg-type quail eggs lost $0.57 \%, 1.14 \%$, and $1.80 \%$.

Egg weight loss is an important parameter for incubation. It has been used to estimate vital gas exchange (Paganelli et al., 1978; Rahn et al., 1979), and has been correlated with embryo metabolism and development rates (Rahn \& Ar, 1980; Burton \& Tullet, 1983).

In the present study, total egg weight loss was measured up to egg transference. Weight loss during incubation was directly influenced by weight loss during the storage. Eggs stored for longer periods presented lower levels of weight loss during incubation as compared to fresh incubated eggs or those that were submitted to a few days of storage. This relation was easier to observe in meat-type quail eggs than in eggtype quail eggs.

All hatched chicks were weighed. However, no correlation was found between storage length and chick body weight, which is consistent with the findings of Petek et al.(2005), and opposed to Sachdev et al. (1988), who reported higher body weight of quails hatched from eggs stored during a short period.

\section{CONCLUSION}

The present study showed that eggs of meat- and egg-type quails presented high hatchability up to 10 days of storage in a refrigerated room $\left(20^{\circ} \mathrm{C}\right)$, and that storage length from 1 to 14 days influenced weight loss of Japanese quail eggs during incubation.

\section{REFERENCES}

Arora LL, Kosin IL. Developmental response of early turkey and chicken embryos to preincubation holding of eggs: Inter-and intraspecies differences. Poultry Science 1966; 45:958-970.

Asmundson VS, MacLlriath JJ. Preincubation tests with turkey eggs. Poultry Science 1948; 27:394-401.

Burton FG, Tullet SG. A comparison of the effect of eggshell porosity on the respiration and growth of domestic fowl, duck and turkey embryos. Comparative Biochemistry and Physiology 1983; 75(A): 167-174

Becker WA. The storage of white leghorn chicken eggs in plastic bags. Poultry Science 1964; 43:1109-1112.

Brake J, Walsh TJ, Vick SV. Relationship of egg storage time, storage conditions, flock age, eggshell and albumen characteristics, incubation conditions, and machine capacity to broiler hatchability- Review and model synthesis. Zootechnia International 1993; 16(1): 30-41. 


\section{Romao JM, Moraes TGV, Teixeira RSC, Cardoso WM, Buxade CC}

Fasenko GM, Robinson FE, Whelan Al, Kremeniuk KM, Walker JA. Prestorage incubation of long-term stored broiler breeder eggs: 1.Effects on hatchability. Poultry Science 2001a; 80:1406-1411.

Fasenko GM, Christensen VL, Wineland MJ, Petitte JN. Examining the effects of prestorage incubation on turkey breeder eggs on embryonic development and hatchability of eggs stored for four or fourteen days. Poultry Science 2001b; 80:132-138.

Funk EM, Biellier HV. The minimum temperature for embryonic development in the domestic fowl (Gallus domesticus). Poultry Science 1944; 23:538-540.

Funk EM, Forward J. Effect of holding temperature on hatchability of chicken eggs [Bulletin 732]. Columbia (MO): Missouri Agricultural Experimental Station.

IBGE - Instituto Brasileiro de Geografia e Estatística. Census of Agriculture 2002 [cited 2006 jan 2]. Available from: http:// www.ibge.gov.br/ibgeteen/datas/pecuaria/home.html.

Kaufman L. An experimental study of the effects of storage on embryonal development of hens' eggs. Proceedings of the $7^{\text {th }}$ World's Poultry Congress Exposition; 1939; Cleveland, Ohio. Estados Unidos. p. 186-187

Kuurman WW, Bailey BA, Koops WJ, Grossman M. Influence of storage days on the distribution for time of embryonic mortality during incubation. Poultry Science 2002; 81:1-8.

Mather CM, Laughlin KF. Storage of hatching eggs: The interaction between parental age and early embryonic development. British Poultry Science 1979; 20:595-604.

Mayes FJ, Takeballi MA. Storage of the eggs of the fowl (Gallus domesticus) before incubation. World's Poultry Science Journal 1984; 40:131-140.

Meijerhof R. Pre-incubation holding of hatching eggs. World's Poultry Science Journal 1992; 48:57-68.

Meir M, Nir A, Ar A. Increasing hatchability of turkey eggs by matching incubator humidity to shell conductance of individual eggs. Poultry Science 1984; 63:1489-1496.

Paganelli CV, Ackerman RA, Rahn $\mathrm{H}$. The avian egg: In vitro condutances to oxygen, carbon dioxide, and water vapor in late development. In: Piiper J, editor. Respiratory function in birds, adult and embryonic. Berlin: Springer-Verlag; 1978. p.212-218.

Petek M, Baspinar H, Ogan M, Balci F. Effects of egg weight and length of storage period on hatchability and subsequent laying performance of quail. Turkish Journal of Veterinary and Animal Sciences 2005; 29:537-542.

Rahn $\mathrm{H}, \mathrm{Ar} \mathrm{A}$. The avian egg: Incubation time and water loss. Condor 1974; 76:147-152.

Rahn H, Ar A, Paganelli CV. How bird eggs breathe. Scientific American 1979; 240:46-55.

Rahn H, Ar A. Gas exchange of the avian egg: time, structure and
Effect of Egg Storage Length on Hatchability and Weight Loss in Incubation of Egg and Meat Type Japanese Quails

function. American Zoologist 1980; 20:477-484.

Rahn H, Christensen VL, Edens FW. Changes in shell conductance, pores, and physical dimensions of egg and shell during the first breeding cycle of turkey hens. Poultry Science 1981; 60:2536-2541.

Sachdev AK, Ahuja SD, Thomas PC, Agrawal SK. Effect of egg weight and storage periods of hatching eggs on growth of chicks in Japanese quail. Indian Journal of Poultry Science 1988; 23:14-17.

Samli HE, Agma A, Senkoylu N. Effects of storage time and temperature on egg quality in old laying hens. Journal of Applied Poultry Research 2005; 14:548-553.

Scott TA, Silversides FG. The effect of storage and strain of hen on egg quality. Poultry Science 2000; 79:1725-1729.

Scott TA, Mackenzie CJ. Incidence and classification of early embryonic mortality in broiler breeder chickens. British Poultry Science 1993; 34:459-470.

Shanaway MM. Quail production systems. Ankara (TUR): Kardelen Ofset Publishing House; 1998. p. 40-48.

Sittmann K, Abplanalp H, Meyerdick CF. Extended storage of quail, chicken, and turkey eggs.1. Hatchability and embryonic mortality. Poultry Science 1971; 50(3):681-688.

Soliman FNK, Rizk RE, Brake J. Relationship between shell porosity, shell thickness, egg weight loss, and embryonic development in Japanese quail eggs. Poultry Science 1994; 73:1607-1611.

Statistix. Statistix for windows manual analytical software. Version 1.0; 1996.

Walsh TJ. The effects of flock age, storage humidity, carbon dioxide, and length of storage on albumen characteristics, weight loss and embryonic development of broiler eggs [thesis]. Raleigh (NC): North Carolina State University; 1993.

Walsh TJ, Rizk RE, Brake J. Effects of temperature and carbon dioxide on albumen characteristics, weight loss, and early embryonic mortality of long stored hatching eggs. Poultry Science 1995; 74: 1403-1410.

Whitehead CC, Maxwell MH, Pearson RA, Herron KM. Influence of egg storage on hatchability, embryonic development and vitamin status in hatching broiler chicks. British Poultry Science 1985; 26:221-228.

Yoo $\mathrm{BH}$, Wientjes $\mathrm{E}$. Rate of decline in hatchability with preincubation storage of chicken eggs depends on genetic strain. British Poultry Science 1991; 32:733-740. 